\title{
GYPSUM KARST GEOHAZARDS IN CHINA
}

Lu Yaoru. Institute of Hydrogeology and Engineering Geology, Zhengding, Hebei 050803, China

Anthony H.Cooper. British Geological Survey, Keyworth, Nottingham, NG12 5GG UK.

Published in

LU YAORU AND COOPER, A.H. 1997. Gypsum karst geohazards in China. 117-126 in BECK, F.B. and STEPHENSON, J.B (Editors)

The Engineering Geology and Hydrogeology of Karst Terranes. Proceedings of the Sixth Multidisciplinary Conference on Sinkholes and the Engineering and Environmental Impacts of Karst Springfield/Missouri/6-9 April 1997. A.A.Balkema, Rotterdam.

This version is a pre-press version with and additional later diagram and may contain minor differences to the published version. Please respect copyright and refer to the published version for the definitive information

\section{ABSTRACT}

China has the worlds largest proven gypsum $\left(\mathrm{CaSO}_{4} \cdot 2 \mathrm{H}_{2} \mathrm{O}\right)$ resources in the world. The gypsum ranges from pre-Cambrian to Quaternary in age and occurs in varied geological environments. The rapid dissolution rate of gypsum means that gypsum karst development can be very fast, resulting in progressively worsening geohazards. This paper reviews the characteristics of the gypsum deposits and their associated geohazards in China.Three kinds of gypsum karst are discussed. These include karst in massive thick beds of gypsum, karst in thin-bedded gypsum and compound karst in gypsum and carbonate rocks. Some site-specific problems are also examined. In the Shanxi coalfield, breccia pipes, or collapse columns, caused by the dissolution of Ordovician gypsum, penetrate the overlying Carboniferous and Permian coal-bearing sequences resulting in difficult coal mining conditions. In Guizhou Province re-activated gypsum karst is associated with leakage of water through the gypsum from a reservoir. Remedial engineering works have been carried out, but leakage still occurs. Groundwater abstraction from gypsiferous sequences is also problematical. It can yield sulphate-polluted water and cause subsidence problems both through gypsum dissolution and groundwater drawdown.

\section{INTRODUCTION}

China is well known for its wide distribution of carbonate rocks and the spectacular development of its karst scenery. Less known is the development of karst in the sulphate rocks, gypsum $\left(\mathrm{CaSO}_{4} \cdot 2 \mathrm{H}_{2} \mathrm{O}\right)$ and anhydrite $\left(\mathrm{Ca} \mathrm{SO}_{4}\right)$. Gypsum dissolves much more rapidly than limestone, and geological hazards related to gypsum dissolution can evolve on a human rather than a geological timescale. Gypsum and anhydrite are economically important industrial minerals which are widely used in industry. China has the largest reserves of gypsum in the world and is the second largest producer (Chinese Institute of Geology and Mineral Resources Information, 1993). In addition to the economic importance of gypsum as a mineral it constitutes a geological hazard responsible for subsidence, water pollution and difficult engineering problems. It is especially dangerous to structures for water storage and control and in the foundations of large buildings and engineering works.

\section{DISTRIBUTION AND GENERAL CHARACTERISTICS OF GYPSUM IN CHINA}

Gypsum is distributed throughout most of the provinces and autonomous regions of China; as a mineral resource it is exploited in 23 of these. It is particularly exploited in Shandong, Inner Mongolia, Qinghai, Hunan, Hebei, Ningxia,Anhui and Sichuan; these areas yielded 90 percent of all China's production. In 1991 it was worked in 152 major mines. The genesis and geological conditions of deposition (Lu Zhicheng, 1981; Tao Weiping, 1981; Lu Yaoru, 1986; Chinese Institute of Geology and Mineral Resources Information, 1993) allow the main gypsum deposits to be broadly classified into four main depositional types: marine deposits, lacustrine deposits, thermal process deposits and karstic and secondary process deposits (Figure 1). Karst features are well developed in the massive and thinly bedded marine and lacustrine deposits. In the minor deposits the presence of soluble gypsum may also be very important in mining and engineering works. To avoid the geohazards related to the various types of gypsum it is important to consider the varied nature of the deposits and the different ways in which karstification has occurred in them.

\section{THE KARSTIFICATION OF GYPSUM AND ANHYDRITE IN CHINA}

The karstification of gypsum (and to a much lesser extent the karstification of anhydrite) are dependent on the physical nature of the deposit, the characteristics of the adjacent strata and the hydrogeological regime, either past or present. The majority of the gypsum deposits that exist are of secondary origin. These were originally deposited as gypsum, or anhydrite (mainly in marine or lacustrine environments) and buried by later deposits. Upon burial the gypsum was dehydrated to anhydrite with a loss of volume (Mossop \& Shearman, 1973). Upon exhumation, and in the presence of water, the anhydrite hydrated back with an associated increase in volume of $63 \%$ to produce secondary gypsum. When this happens folding and brecciation of the gypsum and associated rocks can occur with the common development of abundant fibrous gypsum veins. With continued contact with groundwater the gypsum dissolves and gypsum karst 
can develop. Anhydrite is also soluble in water and karst can also develop in it, but is much less common. The rate of gypsum dissolution is very fast and in normal river and cave conditions of water flow, one metre of gypsum can easily be dissolved in one year (James et al., 1981).

\begin{tabular}{|c|c|c|c|c|}
\hline Type & Sub-type & Basic Features & Gypsum karst & Distribution \\
\hline \multirow[t]{2}{*}{$\begin{array}{l}\text { Marine } \\
\text { Deposits }\end{array}$} & $\begin{array}{l}\text { Massive, } \\
\text { thick-bedded }\end{array}$ & $\begin{array}{l}\text { Gypsum (or anhydrite) as massive } \\
\text { or thick layers associated with } \\
\text { carbonate rocks and to a lesser } \\
\text { extent with clastic rocks. }\end{array}$ & $\begin{array}{l}\text { Karst passages, } \\
\text { caves and collapse } \\
\text { columns and } \\
\text { breccias }\end{array}$ & $\begin{array}{l}\text { Taiyuan of Shanxi Province } \\
\text { (Ordovician, Fengfeng Formation); } \\
\text { Tianzhu of Gansu Province } \\
\text { (Ordovician); Zhongwei of Ningxia } \\
\text { Province (Carboniferous) }\end{array}$ \\
\hline & Thin-bedded & $\begin{array}{l}\text { Gypsum (or anhydrite) as thin } \\
\text { interbeds with carbonate rocks, } \\
\text { halides and clastic rocks. }\end{array}$ & $\begin{array}{l}\text { Karst breccias, } \\
\text { passages and } \\
\text { collapse columns }\end{array}$ & $\begin{array}{l}\text { Throughout North China, parts of } \\
\text { Northeast China, Northwest China and } \\
\text { South China. }\end{array}$ \\
\hline \multirow[t]{2}{*}{$\begin{array}{l}\text { Lacustrine } \\
\text { Deposits }\end{array}$} & $\begin{array}{l}\text { Massive, } \\
\text { thick-bedded }\end{array}$ & $\begin{array}{l}\text { Gypsum (or anhydrite) formed in } \\
\text { red clastic rock (with only minor } \\
\text { amounts in lacustrine carbonate } \\
\text { rocks) }\end{array}$ & $\begin{array}{l}\text { Karst passages and } \\
\text { small cave system } \\
\text { collapses }\end{array}$ & $\begin{array}{l}\text { Yinchen of Hebei Province (Lower } \\
\text { Tertiary); Tongxin of Ningxia Province } \\
\text { (Qingshuiyin Formation, Tertiary); } \\
\text { E’Tuoke Qi of SW Inner Mongolia } \\
\text { (Tertiary) }\end{array}$ \\
\hline & $\begin{array}{l}\text { Thin and } \\
\text { lenticular } \\
\text { bedded }\end{array}$ & $\begin{array}{l}\text { Gypsum (or anhydrite) deposited } \\
\text { as thin beds or lenses with red } \\
\text { clastic rocks and halides. }\end{array}$ & $\begin{array}{l}\text { Caves and corroded } \\
\text { fissures, collapsed } \\
\text { columns and breccia }\end{array}$ & $\begin{array}{l}\text { Widespread in faulted basins in North } \\
\text { and South China. }\end{array}$ \\
\hline \multirow[t]{3}{*}{$\begin{array}{l}\text { Thermal } \\
\text { Process } \\
\text { Deposits }\end{array}$} & Metasomatic & $\begin{array}{l}\text { Gypsum, after anhydrite, formed } \\
\text { during metamorphism in the } \\
\text { contact zone between intrusive } \\
\text { rocks and carbonate rocks. }\end{array}$ & $\begin{array}{l}\text { Corroded fissures } \\
\text { and small cave } \\
\text { systems }\end{array}$ & Daye and Huangshi of Hebei Province \\
\hline & $\begin{array}{l}\text { Volcanic } \\
\text { replacement }\end{array}$ & $\begin{array}{l}\text { Gypsum, after anhydrite, formed } \\
\text { as lenses mainly in andesites, } \\
\text { andesitic tuffs and metaquartzites. }\end{array}$ & $\begin{array}{l}\text { Minor dissolution } \\
\text { features }\end{array}$ & $\begin{array}{l}\text { Ma'anshan and Xiangshan of Anhui } \\
\text { Province }\end{array}$ \\
\hline & $\begin{array}{l}\text { Regional } \\
\text { metamorphic }\end{array}$ & $\begin{array}{l}\text { Gypsum, after anhydrite, formed } \\
\text { in metamorphic rocks such as } \\
\text { marble schists }\end{array}$ & $\begin{array}{l}\text { Thermal karst } \\
\text { passages }\end{array}$ & Fengchen of Liaoning Province \\
\hline \multirow{2}{*}{$\begin{array}{l}\text { Karstic } \\
\text { and } \\
\text { Secondary } \\
\text { Hydration } \\
\text { Process } \\
\text { Deposits }\end{array}$} & Cave deposits & $\begin{array}{l}\text { Widespread, minor deposits } \\
\text { formed by compound } \\
\text { karstification and crystallisation } \\
\text { processes. }\end{array}$ & $\begin{array}{l}\text { Depositional } \\
\text { features as thin beds } \\
\text { or dykes }\end{array}$ & $\begin{array}{l}\text { Suiyang of North Guizhou Province, } \\
\text { SW Shanxi Province; NW Beijing } \\
\text { Province. }\end{array}$ \\
\hline & $\begin{array}{l}\text { Fissure and } \\
\text { vein deposits }\end{array}$ & $\begin{array}{l}\text { Secondary deposits formed by the } \\
\text { hydration of anhydrite to gypsum } \\
\text { with gypsum deposition as fibrous } \\
\text { gypsum veins. }\end{array}$ & $\begin{array}{l}\text { Minor to moderate } \\
\text { dissolution features }\end{array}$ & $\begin{array}{l}\text { Guangxi and Shangxi provinces, and } \\
\text { most regions with original marine or } \\
\text { lacustrine gypsum deposits. }\end{array}$ \\
\hline
\end{tabular}

Figure 1. The main geological settings of gypsum deposits in China

\section{Karstification of massive gypsum deposits}

The karstification of massive gypsum deposits depends on their thickness, the nature of the adjacent strata and the hydrological regime. In south China subtropical climatic conditions have existed for a long period. In these conditions gypsum dissolution rates are high, the caves enlarge rapidly and collapse readily occurs. Because of this collapse, there are fewer well-developed cave systems in the gypsum than there are in the limestone. In the Suiyang area, situated to the north of Guizhou Province, there is a mixed limestone and gypsum karst developed in the Middle Cambrian Shilengshui Formation. There are many thick and medium beds of gypsum in the carbonate rocks, and these have been karstified for a prolonged period. As a result an area of gypsum $5 \mathrm{~km}$ long and $3 \mathrm{~km}$ wide has been largely dissolved. Some of the gypsum has then been redeposited as secondary gypsum deposits in the Shigao Dong Cave developed in the 
carbonates. Shigao means gypsum in Chinese, and the secondary gypsum deposits have been exploited, as mineral deposits, by the local people for more than one hundred years (Figure 2, I; map data from Chen Jiangeng).

In Shanxi Province gypsum is present the Middle Ordovician Fengfeng Formation. It contains up to about 60 percent of secondary gypsum, present as thick massive beds, nodular gypsum and gypsum interbedded with mudstone and dolomite (Sha et at., 1989). The formation rests on the Majiagou Formation which also contains some gypsum and is the major regional aquifer. In the Tiejingou deposit near Yangquan the Fengfeng Formation ranges in thickness from several tens to more than one hundred metres. Within the formation large palaeokarst caves, situated in the present vadose zone, have collapsed and are filled with breccia. However, karst fissures are still undergoing dissolution and enlargement (examples of these are shown in figure 2). In both north and south China the active dissolution of gypsum, indicated by sulphate-rich springs, confirms that the gypsum karst is still evolving.

I

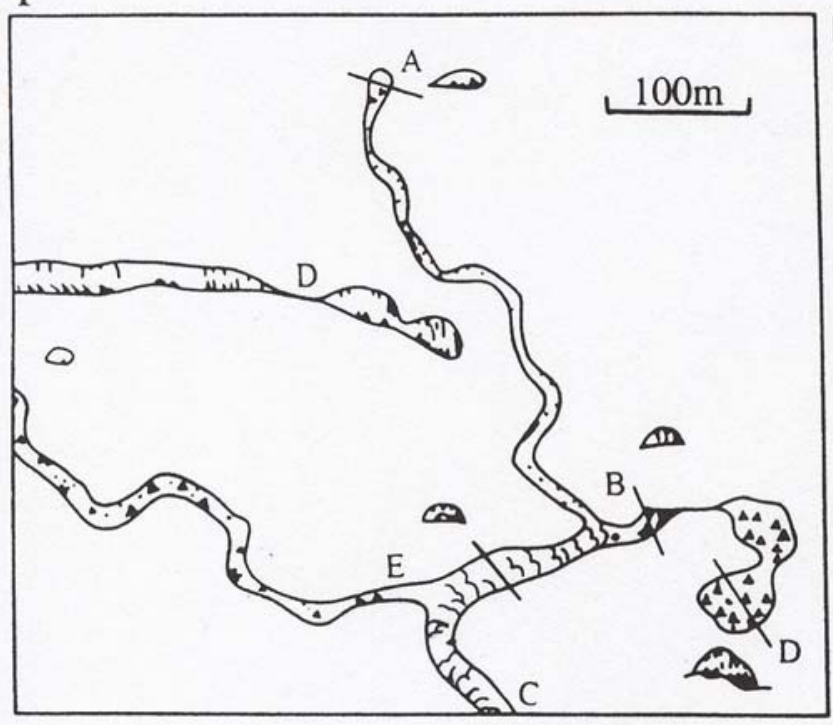

II

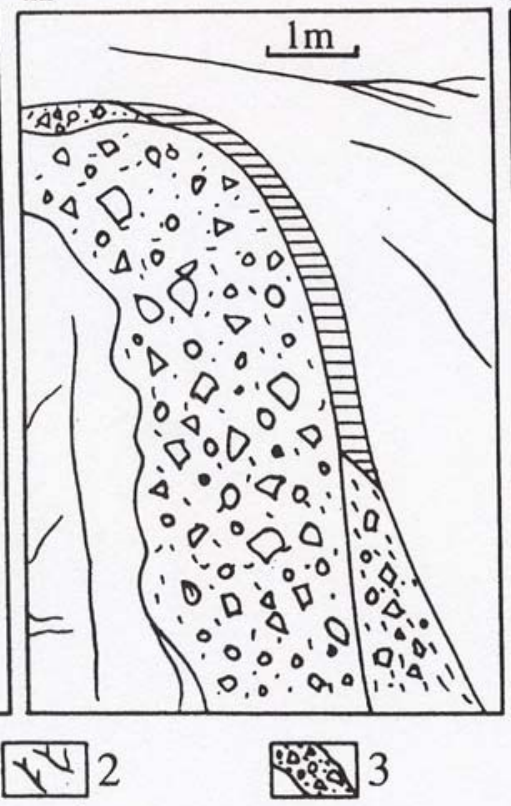

III

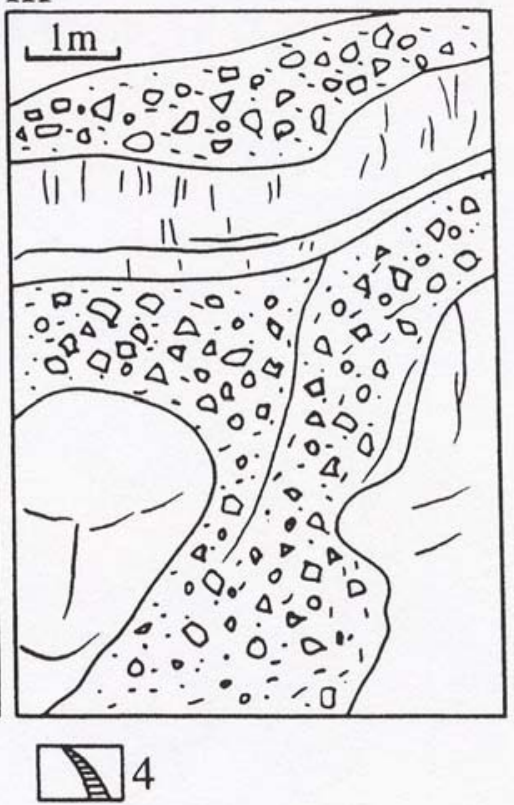

Figure 2. Some cave and collapse deposits related to gypsum karst development: I. Gypsum deposits in Shigao Dong Cave deposited following the nearby dissolution of gypsum in the Shilengshui Formation, Suiyang, north Guizhou Province. II. Collapsed and filled palaeokarst caves at Xizhen 10km west of Taiyuan. III. Collapsed and filled palaeokarst caves at Tiejingou 19km northeast of Yangquan, Shanxi Province. Legend: 1 . Secondary gypsum deposits in the cave. 2. Massive gypsum with fissures. 3. Collapsed fill materials, and materials caused by cave erosion and deposition. 4. Recent corroded fissures.

In a semi-arid environment undergoing uplift, more rapidly than erosion, gypsum cave systems and gypsum karst can be preserved and remain stable. In this situation palaeokarst, such as that originally developed under phreatic conditions in the Ordovician Fengfeng Formation of the Shanxi Province, has been uplifted above the water table and preserved. In the Fengfeng Formation the dissolution of the gypsum has caused the formation of extensive breccia beds with associated breccia pipes, or collapse columns, that have propagated upwards through the working Shanxi Coalfield (Wang Rui, 1982; Zhang Fenqi and Han Xingrui, 1983; Zhang Zigan, 1982). Peservation of gypsum karst is likely when climatic conditions change causing a reduction in the availability of water to the natural systems. In this way the gypsum karst of southwest Oklahoma (Johnson, 1990) was preserved. Pollen/spore samples from underground deposits here, collected by Lu Yaoru in 1992, have yielded a temperate, but dry forest/grassland assemblage. This contrasts with the present semi-dry climatic conditions that occur there now (Lu Yaoru, 1996).

In active karstification situations gypsum can dissolve very rapidly and caves can quickly enlarge, or amalgamate, become unstable and collapse. When this occurs collapse columns or breccia pipes can propagate upwards and cause surface collapse (Cooper 1986 and 1995 ; Andrajchouk and Klimchouk, 1993). The sizes of the breccia pipes and collapses relates directly to the thickness and strength of the gypsum deposits. The more massive, thick and homogeneous the deposit, the larger are the caves that can be supported and consequently the larger the collapses and breccia pipes. When the gypsum between the collapse columns also dissolves the whole sequence effectively founders onto an irregular bed of breccia.

The nature of the underlying and overlying strata adjacent to the gypsum also has a profound influence on the way gypsum karst develops. In sequences where the adjacent rocks are largely impervious the karst can only develop along the joints in the gypsum. In phreatic situations, where the gypsum is underlain, or overlain, by porous dolomites or sandstones, water enters the gypsum in a diffuse way. When this happens dissolution progresses on many fronts and maze cave systems can develop, such as those observed in the Ukraine (Andrajchouk and Klimchouk, 1993). In this situation much of the dissolution occurs at the contacts with the adjacent strata 
which may also be karstified. In the maze caves the passages range from joint-controlled networks of small stable caves with little dissolution, to networks of actively dissolving conduits with large and unstable cavities; these commonly have subsidence associated with them.

\section{Karstification of interbedded gypsum and carbonate rocks}

Where thin beds of gypsum are interbedded with porous beds of limestone or dolomite (or sandstone), the potential for the hydration of anhydrite and the dissolution of the resultant gypsum is large. When anhydrite hydrates to gypsum, the expansion can cause brecciation of the mineral, brecciation of the adjacent rock, and injection of fibrous gypsum veins; such deposits are present in the Ordovician Fengfeng Formation (Wang Rui, 1982; Xiang Shijun et al., 1993). When dissolution of the gypsum occurs, cavities result followed by collapse and the formation of layered breccia deposits. Because dissolution is not uniform throughout the deposits, caves can also develop allowing further erosion of the collapsed material. Breccia pipes or collapse columns can develop in this type of strata (Lu Yaoru et al., 1982), but may be of smaller dimensions than those developed in the more massive gypsum rocks. This is due to the presence of numerous discontinuities in the bedded sequence and the piecemeal failure of the thin-bedded rock, which will span smaller distances. Where the sequence comprises interbedded gypsum and insoluble, or less soluble, rocks a breccia, largely composed of the insoluble components, can develop along the level of the former gypsum beds. This is the situation that formed breccias at numerous levels, and collapse columns of breccia penetrating much of the sequence, in the Fengfeng Formation of Shanxi Province (Wang Rui, 1982; Xiang Shijun et al., 1993).

Where gypsum is in contact with adjacent carbonate rocks, the water chemistry associated with the dissolution phenomenon is different to that for gypsum alone, or for limestone alone. The presence of gypsum together with carbonate rocks will usually cause a compound karstification effect. Waters rich in calcium carbonate can aggressively dissolve gypsum and simultaneously deposit calcite (Wigley, 1973). When this occurs the breccias caused by the dissolution of the gypsum may be cemented. Carbonate-cemented breccias, possibly formed by this mechanism, occur in the Fengfeng Formation. Gypsum dissolves easily in flowing water and increases the amount of sulphate in the water. However, the solubility of gypsum in calcium carbonate-rich waters may be decreased by the common ion effect. Conversely, the presence of sodium, magnesium and chloride ions (possibly derived from interbedded dolomites and halite beds) can enhance the dissolution of gypsum (James, 1992 and references therein). Experimental work by Lu Yaoru and others (Lu Yaoru et al., 1966; Lu Yaoru et al., 1973) shows that the presence of sulphate in the water increases the dissolution rate for dolomite. For water with an $\mathrm{SO}_{4}{ }^{2-}$ content of $1 \mathrm{mg} / \mathrm{l}$ the dissolution amount for dolomite was $1.67 \mathrm{mg} / \mathrm{l}$ while that for limestone was only $0.94 \mathrm{mg} / \mathrm{l}$. The result of this groundwater chemistry on karstification is that very intense and pervasive leaching of the carbonate deposits, especially dolomites, can occur resulting in a honeycomb structure of very little strength. The dissolution of the gypsum, when it is complete, can leave just an insoluble residue, commonly of silt or clay.

\section{Karstification of thin and interbedded gypsum deposits in mudstone}

In thin-bedded deposits of gypsum interbedded with mudstone, and in sequences of mudstone with abundant fibrous gypsum veins, cavities may not develop, but dissolution by shallow circulating groundwater can remove the gypsum completely from a zone near the outcrop. When this happens the enveloping mudstone collapses leading to a disturbed deposit with little strength; these can cause difficult engineering conditions.

\section{ENVIRONMENTAL IMPACT OF GYPSUM KARST IN CHINA}

\section{Sulphate-rich groundwater}

Because gypsum is readily soluble in water, the presence of gypsiferous strata, in or near to water abstraction boreholes, can result in sulphate-rich groundwater being abstracted. In Shanxi Province an area in excess of several hundred square kilometres suffers from poor groundwater quality as a result of gypsum dissolution. (Figure 3). The water with a high sulphate content (in excess of the World Health Organisation 1984 limit of $400 \mathrm{mg} / \mathrm{l}$ ) is unsuitable for domestic water supply and for irrigation schemes. Despite this, in the area around Qingxu (40km SSW of Taiyuan, the capital of Shanxi Province) artesian water (Figure 3, $\mathrm{S}_{1}$ and Figure 4) emerges from boreholes drilled into the Fengfeng Formation where it is faulted against less pervious rock and the Quaternary fill of the Shanxi basin to the east. The artesian sulphate-rich water is used to fill ponds for fish farming and does not appear detrimental to the fish. At the historical monument of the Jinci Spring, in a similar geological setting, the sulphate content of the water is less and was reported to be 260 ppm by Pan Shulan (1989). This lower sulphate content is due to mixing of the karst waters with surface water (Wei Keqin et al., 1989). On the outskirts of Taiyuan, gypsiferous geothermal water (Figure 3, $\mathrm{S}_{2}$; Figure 5) is currently being exploited from boreholes to supply a new spa. The source is the Majiagou Formation below the gypsiferous Fengfeng Formation, but at depth this water is also high in sulphate derived from the overlying formation. 


\begin{tabular}{|l|l|l|l|l|l|l|l|l|l|l|l|l|l|}
\hline & \multicolumn{4}{|l}{ Positive ions ppm } & \multicolumn{4}{l|}{ Negative ions ppm } & & & \\
\hline & $\mathrm{K}$ & $\mathrm{Na}$ & $\mathrm{Ca}$ & $\mathrm{Mg}$ & Total & $\mathrm{HCO}^{3-}$ & $\mathrm{Cl}^{-}$ & $\mathrm{SO}_{4}{ }^{2-}$ & Total & $\mathrm{PH}$ & Buried depth & Temp. \\
\hline $\begin{array}{l}\text { Qinxue } \\
\text { karst } \\
\text { water S }\end{array}$ & 11.9 & 20.0 & 466.2 & 105.9 & 604.1 & 204 & 11 & 1407 & 1624 & 7.3 & $\begin{array}{l}200-300 \\
\text { metres }\end{array}$ & $24^{\circ} \mathrm{C}$ \\
\hline $\begin{array}{l}\text { Thermal } \\
\text { water S }\end{array}$ & 9.7 & 23.5 & 433 & 114 & 581 & & 14.2 & 1373 & 1591 & 7.3 & $\begin{array}{l}\text { Deep zone } \\
600+\text { metres }\end{array}$ & $39^{\circ} \mathrm{C}$ \\
\hline
\end{tabular}

Figure 3. Groundwater quality in the Taiyuan area of Shanxi Province

The removal of large amounts of sulphates by water abstraction boreholes could have a detrimental effect on some of the abstraction sites and be a potential source of subsidence in their vicinity. Sulphate-rich groundwater is harmful to ordinary cement. In the gypsum karst areas sulphate-resistant cement is required, this can increase the costs of engineering works for structures that come into contact with this water.

\section{Mining conditions and collapses}

In Chinese coal mines about 2875 karst collapse columns, or breccia pipes, have been found in 45 different mining areas including Shanxi, Hebei, Shandong, Henan and Jiangsu provinces (Li Jinkai and Zhou Wangfang, 1988; Liu Qiren, 1996). Similar collapse columns have also been recorded in the Tanggula Mountains of southwest Qinghai Province (Lu Yaoru, 1986). Most of the collapse columns have been caused by gypsum karst, though some are attributed to limestone collapse. The greatest concentration of collapse columns so far found is within the Xishan Mine, Shanxi Province, where 1300 collapse columns have been recorded in 70 square kilometres (Figure 4).

\begin{tabular}{|l|l|l|l|}
\hline Name of mine & Area exploited $\mathrm{km}^{2}$ & $\begin{array}{l}\text { Number of karst collapse } \\
\text { columns }\end{array}$ & Number of karst collapse columns per km ${ }^{2}$ \\
\hline Yangchuan & 150 & 700 & $2.6-4.5$ \\
\hline Fengxi & 21 & 804 & $43-51$ \\
\hline Huoxian & 11.7 & 410 & $10.2-72$ \\
\hline Xishan, Taiyuan & 18 & 1300 & 70 \\
\hline
\end{tabular}

Figure 4. Some statistics about karst collapse columns with coal mines in Shanxi Province (Communicated by Mr Wang Guixi in 1996).

In the Shanxi coalfield, dissolution of the Ordovician Fengfeng Formation gypsum has produced numerous subsidence pipes, or collapse columns, filled with collapse breccia. These columns, which range in diameter from several tens of metres to several hundreds of metres, penetrate the overlying Carboniferous and Permian coal sequences and some reach the surface. The collapse columns contain foundered materials, other than coal, and when they are encountered underground the local mining name for them is "white wall". They are mainly palaeokarst collapse features and are concentrated in and above the Fengfeng Formation around the margins of the coalfield (Figure 5). Some of these breccia pipes include sedimentary rocks as young as Triassic in age, even though these young rocks have now been eroded from the area (for example: Lu Yaoru, 1986 \& 1993, plate 281). Observations of these features (Lu Yaoru, 1986; Qian Xuepu, 1988) shows that many of the larger breccia pipes penetrate through up to 300-500 metres of overlying rock. The presence of these collapse columns causes very difficult coal mining conditions. Many of the collapse columns reach the surface and contain loose fill material; these act as conduits allowing surface and overlying groundwater to enter the mine workings. Some of the columns connect the underlying carbonate aquifers with the coal workings and allow water to rise from below. Some of the largest inrushes of water in Chinese coal mines have been as a result of mining into these breccia filled pipes (Li Jinkai and Zhou Wangang, 1988). The collapse columns are especially common around the margins of the coalfield where the underlying gypsum approaches outcrop (Figure 5). In the deeper parts of the basin, where anhydrite is present, the collapse columns are not present.

In the northeast of Hebei Province collapse columns have been recorded in the Fangezhuang Coal Mine, 25 km ENE of Tangshan (150km ESE of Beijing). Here a breccia pipe filled with water-bearing collapse deposits penetrates more than 300m upwards into the coal sequences from the underlying Ordovician carbonates and gypsum (Figure 6). This palaeokarst structure allowed up to $12 \mathrm{~m}^{3} / \mathrm{s}$ of water to flood the mine, the total amount of karst water that entered the mine over three months was about 46 million cubic metres (Qian Xuepu, 1988) and surface collapses were associated with the dewatering. The Jingling mine of west Hebei has also suffered serious water inrushes from encountering karst collapse columns.

The palaeokarst collapse features in the Shanxi and Tangshan coalfields are similar to the breccia pipes and subsidence features observed in England (Cooper, 1986, 1995) and the Ukraine (Andrajchouk \& Klimchouk, 1993). By comparison with these it may be 
expected that the pattern of collapse columns or breccia pipes, recorded in the coalfields, relates to the jointing in therock, a feature controlled by the regional structure. Thus, collapse areas lie parallel to the main structural grain of the country in the Shanxi Coalfield. From this observation it can be deduced that the best overall orientation for coal extraction panels in longwall mines will be parallel to, but avoiding, the belts of collapse columns. In most situations this will also be parallel to the main joint direction, which would facilitate mining. Monitoring of the karst water in the coal mines and advanced probing of the workings (as described by Li Jinkai and Zhou Wangang, 1988) has allowed the coal mines to be worked safely.

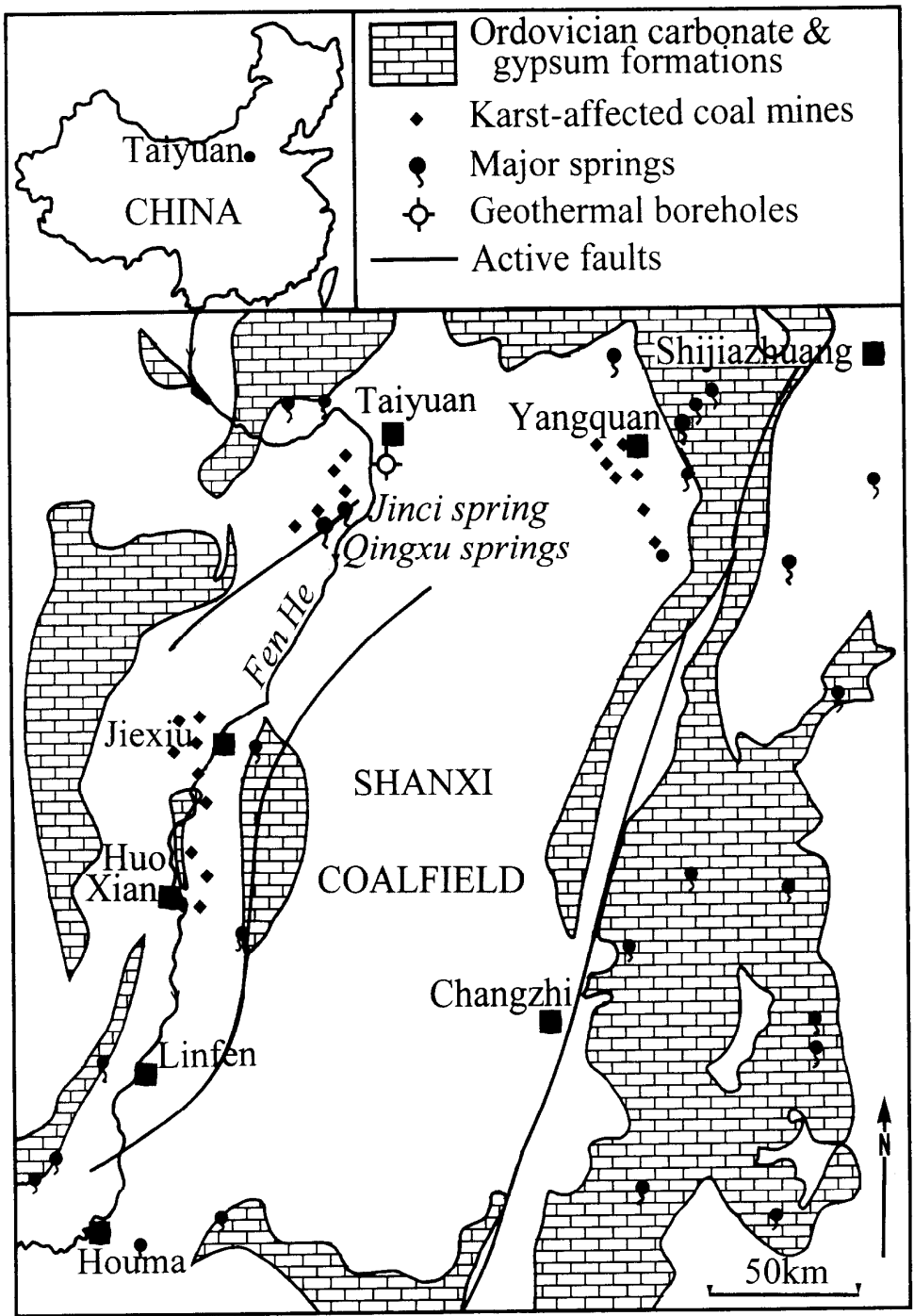

Figure 5. The Shanxi coalfield and the locations of the main karstaffected coal mines and some important springs. The distribution of the Ordovician gypsiferous and carbonate sequences are shown surrounding the coalfield. Figure

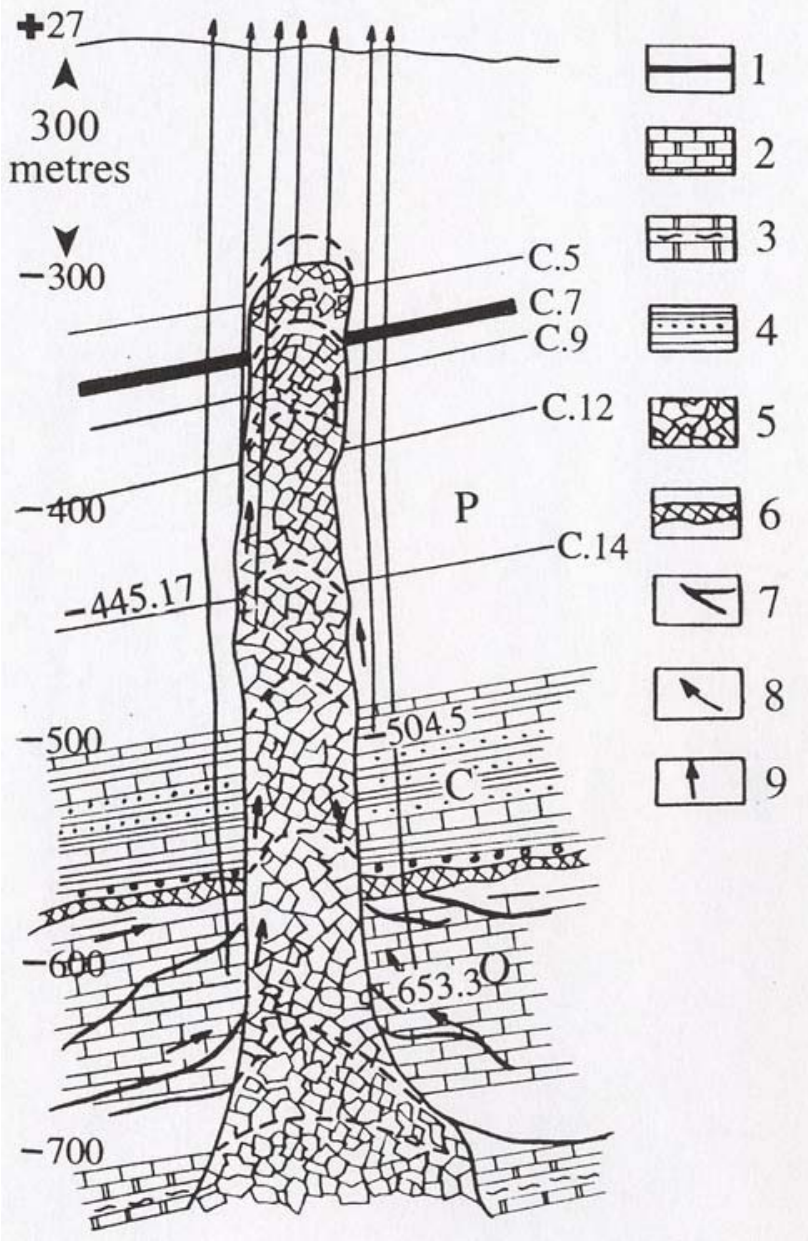

Figure 6. Cross-section through a large collapse column filled with breccia at the Fangezhuan Mine near Tangshan. 1- Permian Shanxi Formation; 2- carbonate rocks; 3carbonate rocks with gypsum; 4- sandstone and shale; 5collapse column showing various stages of its upward progression; 6-palaeokarst horizon between the Ordovician and Carboniferous sequences; 8- direction of water flow; 9boreholes. Compiled from borehole data of the Bureau of Kailuan Mine (Xiang Shijun et al., 1993; Liu Qiren et al., 1996).

Reservoir leakage and associated karst collapse

The construction of dams and reservoirs in gypsum karst areas is difficult, potentially dangerous and can result in leakage and collapse problems. The construction of dams can lead to the reactivation of the karst system with enhanced water flow and associated dissolution problems (James and Lupton, 1978; James, 1992 and references therein; Eraso et al. 1995). If this happens close to a dam, the result could be failure of the structure.

In both north and south China there are dams with leakage problems caused by gypsum karst. The Huoshipo Reservoir, about 20 km WNW of Anshun in Puding County (about 90km SW of Guiyang the capital of Guizhou Province), suffered serious leakage through the 
gypsum karst beneath it (Figures 7 and 8). The Huoshipo Dam is constructed on a mixed gypsum and limestone karst developed in the Triassic Guanling Formation. The reservoir, of capacity 4.7 million cubic metres, is impounded with an earth dam $23 \mathrm{~m}$ high and $200 \mathrm{~m}$ long. No investigation of the underlying geology was undertaken before it was constructed. When the dam was filled to an altitude of $1351.63 \mathrm{~m}$ it suffered a considerable loss of water. This water emerged about 400m downstream of the dam, with an artesian head of several metres, and a flow that reached 237 l/s. This spring (S1 in Figure 7) is known as the "sand spring" (in Chinese) because of the amount of carbonate and clastic sand washed out from it. The discharge from the spring showed a close correlation with the head of water in the reservoir (Figure 8). On each occasion when the reservoir was drained it was found that a series of sinkholes had opened up about 100m behind the dam (Hu Wuzhou, 1988). These have since been sealed with rock fill, plastic membranes and clay cover. A programme of grouting was

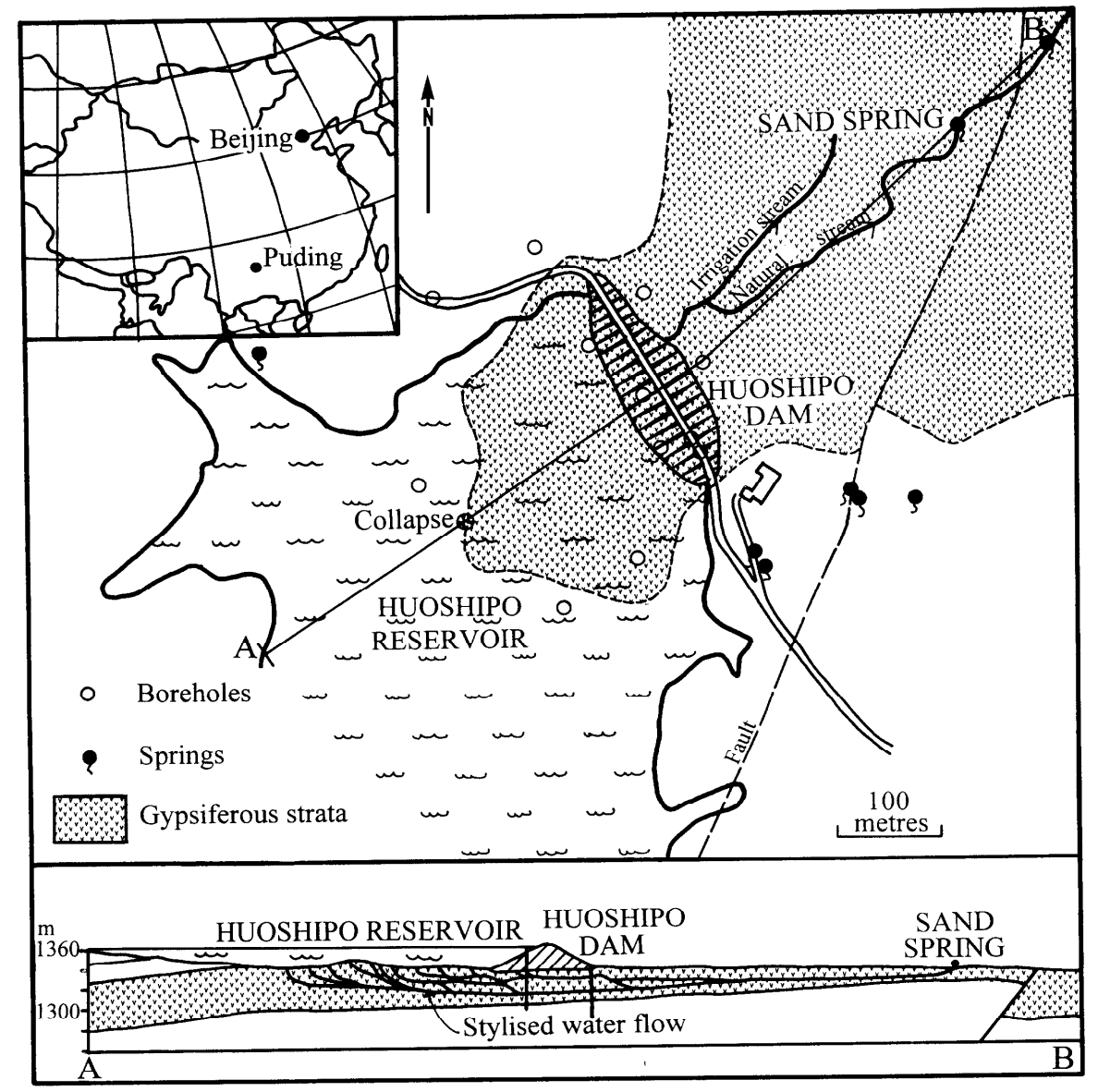

Additional location map figure to accompany Figure 7 (from COOPER, A.H. and CALOW, R. 1998. Avoiding gypsum geohazards: guidance for planning and construction. British Geological Survey Technical Report WC/98/5 ). 

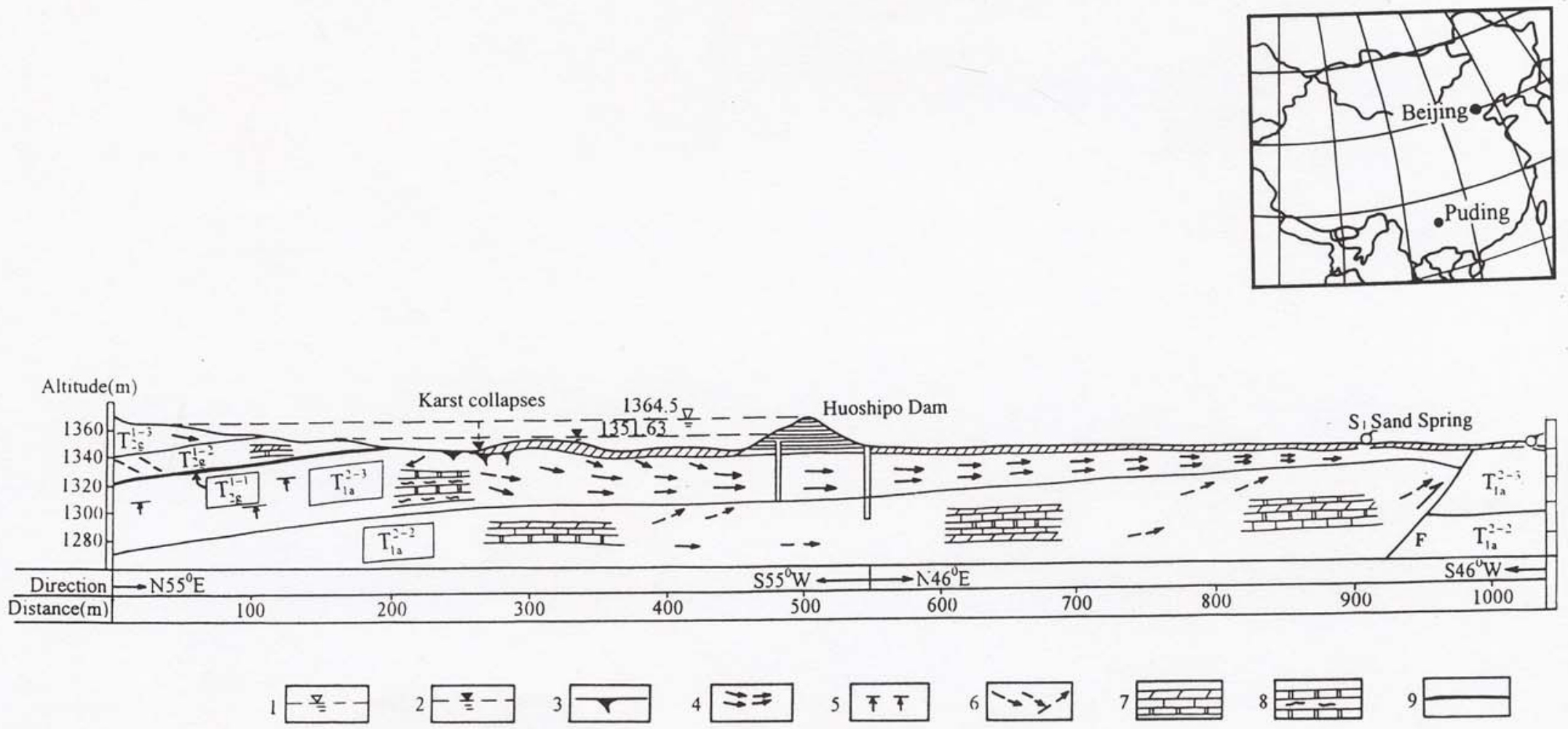

Figure 7. Cross-section through the Huoshipo Dam and Huoshipo Reservoir site showing the likely hydrogeological conditions and water flow beneath the dam. 1-Normal reservoir level; 2-Reservoir level after the karst collapse; 3-Collapses in the reservoir caused by the gypsum karst; 4-Percolating flow in gypsum and dolomite; 5-Artesian water in carbonate rocks; 6-Percolating water in thin carbonate rocks; 7-Thin carbonate rocks; 8-Gypsum and dolomite; 9-Acid tuff. (Information from Jiang Defu) 


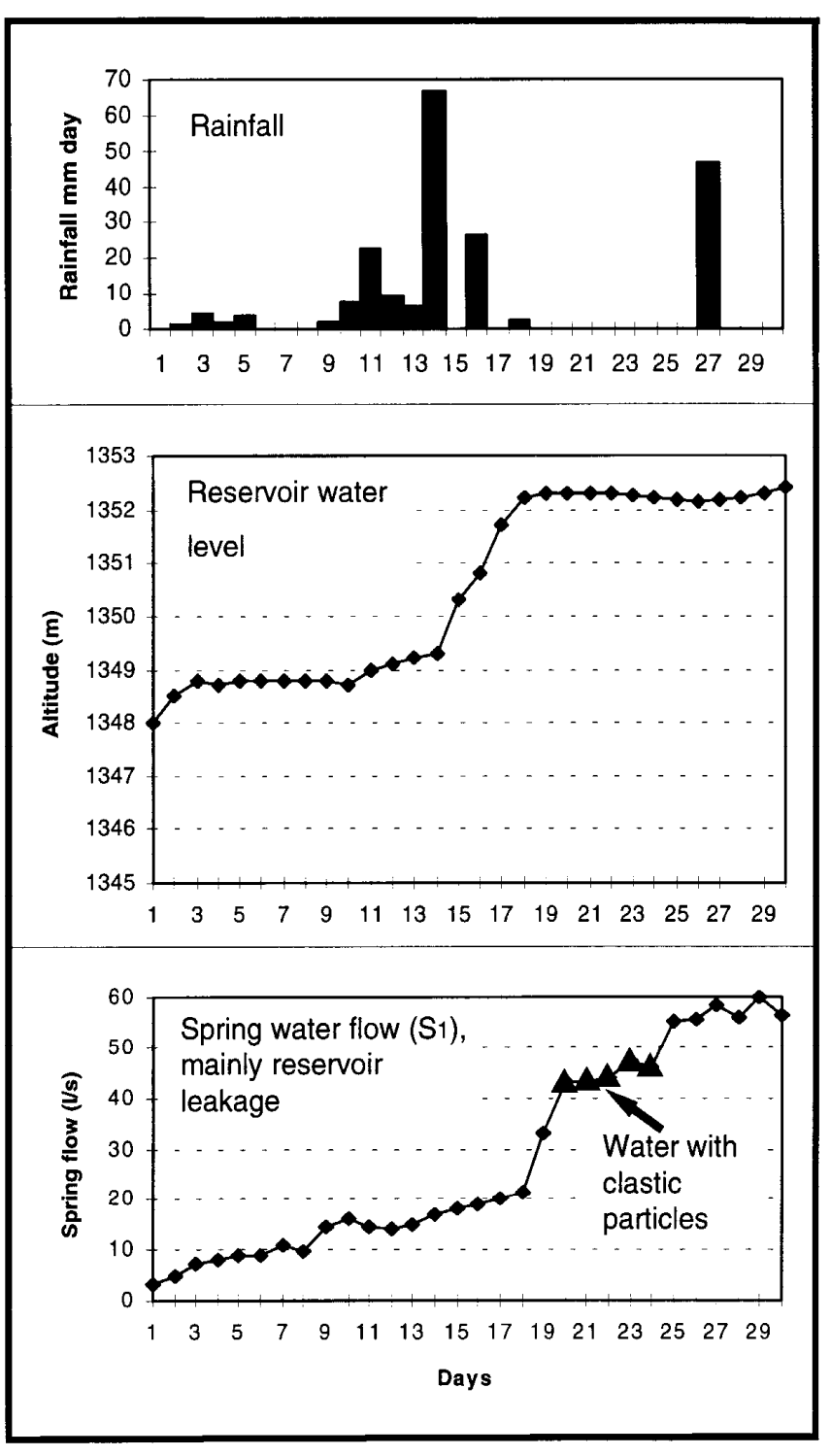

Figure 8. The correlation between the amounts of rainfall, the Huoshipo Reservoir water level and the related amount of water flowing from the Sand Spring for the month of June 1982 (Information from Jiang Defu). also undertaken and a cement grout curtain emplaced, this decreased the flow from the reservoir. While the grouting programme was being undertaken, a cavity $60-70 \mathrm{~cm}$ high was found in one of the boreholes and areas of corroded limestone with a honeycomb structure were also found. The dam is still leaking through the gypsum karst, but the water flow has reduced considerably to about $80 \mathrm{l} / \mathrm{s}$; this is still enough to cause concern. The natural groundwater flow here contributes about $10 \mathrm{l} / \mathrm{s}$ of this flow (Hu Wuzhou, 1988). The water in the dam contains 29-38 $\mathrm{mg} / \mathrm{l}$ of sulphate, but downstream where it emerges at the spring it contains about $200 \mathrm{mg} / \mathrm{l}$. From the increases in sulphate it may be surmised that the dissolution of gypsum beneath the dam and reservoir is continuing and that, in the future, the dam or the reservoir bottom may be affected. The grouting and leakprevention measures that were taken decreased the leakage by about 70 percent, but the gypsum is still dissolving and developing gypsum karst. The structure is being monitored, but the concern is that water passing beneath the grout curtain will cause enlargement of the karst passageways, increase the leakage and possibly destabilise the dam. Another problem is that the leakage from the reservoir is reducing the efficiency of the dam to store water and contribute effectively to the local anti-drought irrigation scheme.

\section{CONCLUSIONS}

Gypsum karst is an important problem in China. The fast dissolution rate of gypsum means that it can quickly cause environmental problems such as subsidence, both naturally and by anthropogenic means. These problems can impact on agricultural, industrial and constructional activities. Any passage of water through gypsiferous sequences can cause dissolution which can be enhanced by human activities such as groundwater pumping for irrigation or mine dewatering. In addition, the construction of water-retaining structures can alter the local water flow and lead to potential dissolution and subsidence problems, with possible failures of structures like dams and canals. Changes to the natural groundwater situation in gypsiferous areas is potentially more dangerous than it is in limestone karst areas. In coalfields, the occurrence of collapse columns related to gypsum dissolution can cause severe mining problems. Some of these problems may be partly predictable by relating the collapse column distribution to the local and regional structures, especially the jointing in the rock. In some of the limestone karst areas gypsum has been neglected as a cause of rapid karst development, and more attention should be paid to its presence.

\section{ACKNOWLEDGEMENTS}

This study is the result of cooperation that has been funded and facilitated by the British Overseas Development Administration (ODA) of the British Foreign Office, under Technical Development and Research (TDR) contract R6490; Gypsum Geohazards: their impact on development. We are very thankful to Dr Tony Waltham for introducing us as co-workers. Our thanks for help with this research go to Chief Engineer Wang Guixi, Senior Hydrologist Guo Wenbing, Professor Han Zi Jun, Senior Hydrogeologist Sun Yunzhong, and Senior Engineer Ma Hong Hai, Engineer Xue Zhi Weng, Engineer Tien Jia, Jiang Defu, Associate Professor Xin Fangming and all his staff at the Puding Karst Research Station and Professor Yang Mingde. Our thanks also go to the many other people in the following Chinese and British institutes that helped with our study: Ministry of Geology and Mineral Resources; Institute of Hydrogeology and Engineering Geology; Shanxi Bureau of Geology; Bureau of Geology and Mineral Resources of Yangquan City; Shanxi Geological Engineering and Exploration Institute; Sichuan Bureau of Geology and Mineral Resources; Guizhou Bureau of Geology and Mineral Resources; Guizhou Normal University; Guangxi Bureau of Geology and Mineral Resources; British Geological Survey. Drs John Bennett and Tony Reedman are thanked for help in arranging the project. Tim Charsley, Rob Evans, Martin Culshaw and Dr Tony Waltham are thanked for reviewing this and earlier versions of the manuscript. A.H.Cooper publishes with permission of the Director, British Geological Survey (N.E.R.C.). 


\section{PLACE NAMES}

The translation of Chinese place names to Pinyin (western script) can be variable. The main spellings used in this paper have been taken from the Chinese Atlas: Zhonghua Renmin Gongheguo Fen Sheng Dituji (Hanyu Pinyinban) Ditu Chubanshe, Zhongguo Beijing, 1977. Where the places mentioned are not in the atlas they have been located relative to a larger named place.

\section{REFERENCES}

Andrajchouk, V. and Klimchouk, A. 1993. Environmental change and human impact on karst in the Western Ukraine. Catena Supplement, 25, 147-160.

Chinese Institute of Geology and Mineral Resources Information. 1993. Mineral Resources of China. China Building Materials Industrial Press. 392pp.

Cooper, A H. 1986. Foundered strata and subsidence resulting from the dissolution of Permian gypsum in the Ripon and Bedale areas, North Yorkshire. 127-139 in Harwood, G.M.and Smith, D.B. (eds). The English Zechstein and related topics. Geological Society of London, Special Publication. No. 22.

Cooper, A.H. 1995. Subsidence hazards due to the dissolution of Permian gypsum in England: investigation and remediation. 23-29 in Beck, F.B. (ed.) Karst Geohazards: engineering and environmental problems in karst terrane. Proceedings of the fifth multidisciplinary conference on sinkholes and the engineering and environmental impacts of karst Gatlinburg/Tennessee/2-5 April 1995. 581pp. A.A.Balkema, Rotterdam.

Eraso, A., Trzhtsinskij, Y. and Castrillo, A. 1995. Dolinas de colapso y karst en yeso en la plataforma cámbrica del esta de Siberia. Boletin Geológico y Minero. Vol. 106-4, 373-378.

Hu Wuzhou. 1988. A study on the formation of Triassic "gypsum-dissolved-strata" in Guizhou Province and the seepage prevention for reservoirs. 1117-1126 in Yuan Daoxian (ed), Karst hydrogeology and karst environment protection; proceedings 21st IAH Conference, 10-15 October 1988, Guilin, China. IAH-AISH Publication. 176, Vol 2.

James, A.N., 1992. Soluble material in civil engineering. Ellis Horwood Ltd, England, 433p.

James, A.N. and Lupton, A.R.R. 1978. Gypsum and anhydrite in foundations of hydraulic structures. Geotechnique. Vol. 3, $249-272$.

James, A.N., Cooper, A.H. and Holliday, D.W. 1981. Solution of the gypsum cliff (Permian Middle Marl) by the River Ure at Ripon Parks, North Yorkshire. Proceedings of the Yorkshire Geological Society, Vol. 43, 433-450.

Johnson, K.S. 1990. Hydrogeology and karst of the Blaine gypsum-dolomite aquifer, southwestern Oklahoma. Oklahoma Geological Survey Special Publication 90-5, Guidebook for Field Trip No. 15, Geological Society of America (Annual Meeting, 1990), 31pp.

Li Jinkai and Zhou Wangang. 1988. Karst groundwater inrush and its prevention and control in coal mines in China. 1075-1082 in Yuan Daoxian (ed), Karst hydrogeology and karst environment protection; proceedings 21st IAH Conference, 10-15 October 1988, Guilin, China. IAH-AISH Publication. 176, Vol 2.

Liu Qiren, Mu Pingzhuan, Jia Xueming, Dong Yuliang, Ma Tan, Zhou Zunye, Sun Jichao, Jia Xiumei, Lin Fengqi, Wang Rui, Yu Guoguang, Xiang Shaoping, Zhang Fawan, Bi Erping, Liu Wensgeng and Bai Xinli. 1996. The hydrogeological characteristics of solid mineral deposits and the methods for its exploration and evaluation in China. China Petroleum Press. [in Chinese].

Lu Yaoru. 1986, Karst in China- landscapes, types, rules. Geological Publishing House [in Chinese; English explanation published in 1993].

Lu Yaoru. 1993, English Explanation of Lu Yaoru (1986) Karst in China- landscapes, types, rules. Institute of Hydrogeology \& Engineering Geology, Chinese Academy of Geological Sciences. Beijing.

Lu Yaoru. 1996. Karst hydrogeological systems and their environmental impacts. in Evolution of karst hydrogeological environments and their engineering impact. Institute of Hydrogeology and Engineering Geology. [in Chinese]. 
Lu Yaoru and Liu Fucan. 1982. The development of karst research and brief discussion on its fundamental aspects and theoretical problems. 25-29 in Selected papers from the Second All China Symposium on Karst. Sponsored by the Geological Society of China, 1978. Guilin Scientific Press. [in Chinese].

Lu Yaoru, Dai Yin and Jia Wenru. 1966. Primary research on dissolution rates of soluble minerals and rocks influenced by water features and temperature. First National Symposium on Karst, sponsored by the geological Society of China. Special Printing by the Institute of Hydrogeology and Engineering Geology, Ministry of Geology and Hydrogeology. [in Chinese].

Lu Yaoru, Jie Xianyi, Zhang Sanlin and Zhao Chengliang. 1973. The development of karst in China and some of its hydrogeological and engineering geological conditions. Acta Geologica Sinica. 1. 121-136. [in Chinese].

Lu Zhicheng. 1981. Approach to the genetic types of gypsum in China. 40-49 in Gypsum Volume. The 1st Symposium on Non-metal Mineral Geology. Geological Society of China. [in Chinese].

Mossop, G.D. and Shearman, D.J. 1973. Origins of secondary gypsum rocks. Transactions of the Institute of Mining and Metallurgy, (Section B: Applied Earth Sciences), Vol. 82, B147-B154.

Pan Shulan. 1989. Isotope study of groundwater resources in Shanxi Province, China. 357-369 in Wang Sijing (Editor) Advances in geoscience (1). Institute of Geology, Academia Sinica, Contributions to the 28th International Geological Congress, Washington DC, USA, July 9-19, 1989.

Qian Xuepu. 1988. The formation of gypsum karst collapse-column and its hydrogeological significance. 1186-1193 in Yuan Daoxian (ed), Karst hydrogeology and karst environment protection; proceedings 21st IAH Conference, 10-15 October 1988, Guilin, China. IAHAISH Publication. 176, Vol 2.

Sha Qingan, Wang Zhaosheng and Yang Xhaoquing. 1989. Gypsum and anhydrite deposits of the Middle Ordovician in North China. 183-191 in Wang Sijing (Editor) Advances in geoscience (1). Institute of Geology, Academia Sinica, Contributions to the 28th International Geological Congress, Washington DC, USA, July 9-19, 1989.

Tao Weiping. 1981. Distribution of gypsum mineral deposits and their significance. 50-54 in Gypsum Volume. The 1st Symposium on Non-metal Mineral Geology. Geological Society of China. [in Chinese].

Wang Rui. 1982. Discussion on the formation of karst collapsed columns in North China. Hydrogeology and Engineering Geology. 1. [in Chinese].

Wei Keqin, Lin Ruifen, Wang Zhixiang. 1989. Environmental isotope investigation of groundwaters in the region of Taiyan, Shanxi Province, China. 147-157 in Academy of Sciences, Developments in Geoscience. Contribution to 28th International Geological Congress, 1989, Washington DC, USA.

Wigley, T.L.M. 1973. Chemical evolution of the system Calcite-Gypsum-Water. Canadian Journal of Earth Sciences. Vol. 10. 306-315.

Xiang Shijun, Liao Rusong, Lu Donghua and Li Yu. 1993. Karst collapses in northern China. 163-173 In Karst Geological Commission, Geological Society of China (Eds). Karst and karst water in north China. Guangxi Normal University Press [in Chinese].

Zhang Fengqi and Han Zingrui. 1983. The Cambrian-Ordovician soluble rocks and karst in North China. Institute of Hydrogeology and Engineering Geology. MGMR (Eds.); Selected papers of karst resources. 73-90.[in Chinese].

Zhang Zhigan. 1982. Karst in Majiagou Limestone (Middle Ordovician) near Nianhziguan karst spring, Shanxi Province - a case example of karst in sulphate-carbonate formations. 14-24 in Selected papers from the second all-China Symposium on Karst. Sponsored by the Geological Society of China. Scientific Press. [in Chinese]. 